\title{
The Effect of Earnings Quality on Cost of Equity Through Information Asymmetry: An Empirical Study of the Manufacturing Companies in the Indonesia Stock Exchange
}

\author{
DEWI MELINDA \\ ZUNI BAROKAH* \\ Universitas Gadjah Mada
}

\begin{abstract}
This research examines the effect of earnings quality on the cost of equity and whether information asymmetry affects the relationship as a mediator. A hundred and twenty-three manufacturing companies listed in the Indonesia Stock Exchange during 2007-2012 were selected through a purposive sampling method. This study uses absolute discretionary accruals (|DA|) to measure earnings quality, bid-ask spread to proxy information asymmetry, and CAPM to measure the cost of equity. Using the bootstrapping method in the hypotheses testing, this study finds a significant negative effect of earnings quality on the information asymmetry. However, there is no support on the positive association between information asymmetry and the cost of equity, as well as the role of information asymmetry as a mediator on the negative association between earnings quality and cost of equity.
\end{abstract}

Keywords: bootstrapping, discretionary accrual, bid-ask spread, capital asset pricing model (CAPM)

Abstrak: Penelitian ini bertujuan untuk menguji pengaruh kualitas laba terhadap kos ekuitas dan apakah asimetri informasi berperan sebagai mediator. Seratus dua puluh tiga perusahaan manufaktur yang terdaftar di Bursa Efek Indonesia selama 2007-2012 dipilih melalui metode purposive sampling. Penelitian ini menggunakan absolute discretionary accruals (|DA|) untuk mengukur kualitas laba, bid-ask spread untuk mengukur asimetri informasi, dan CAPM untuk mengukur biaya ekuitas. Dengan menggunakan metode bootstrapping dalam pengujian hipotesis, penelitian ini menemukan bahwa kualitas laba berpengaruh negatif terhadap asimetri informasi. Namun, tidak ada dukungan pada hubungan positif antara asimetri informasi dan biaya ekuitas, serta peran asimetri informasi sebagai mediator pada hubungan negatif antara kualitas laba dan biaya ekuitas.

Kata Kunci: bootstrapping, discretionary accrual, bid-ask spread, capital asset pricing model (CAPM)

*Corresponding author: zuni.b@ugm.ac.id 


\section{Introduction}

The borderless economy, as a result of the development of the world economy, has caused unlimited capital flows as the borders of a state no longer limit the business processes. This situation increases the complexity in the process of deploying an enterprise, including in the preparation of financial statements as a media of communications between the company and the stakeholder (ADBI, 2014). This complexity should not detract from the quality of the information generated from the financial statements (PWC, 2011).

Indonesia, as one of the countries in the world, is also impacted by economic development. Capital inflows to Indonesia facilitate companies to raise capital, thus increasing the number of listed companies in Indonesia Stock Exchange. In addition to capital inflows, increasing public knowledge about the types of stock investment played a role in increasing demand for stock investment.

The data from the IDX fact book shows high numbers of transactions and flows of public funds into the capital markets accounted by the listed company (see appendix table 1). The number of listed companies and share transactions in the Indonesia capital market for ten-years from 2004 to 2008 is also growing, despite a decline in 2008 and 2009 due to economic crisis. Thus, listed companies have a responsibility to investors and other stakeholders in reporting financial statements.

Accounting information plays a fundamental role as a basis in the capital allocation in the financial markets. An essential characteristic of the quality of accounting information is the extent to which earnings (accrual) mapped in cash flows. A poor mapping of accrual in cash flows will reduce the content and quality of reported earnings (Bhattacharya et al., 2011). As investors have a different capacity in processing financial information, the risk of information asymmetry is increasing.

The analytical models by Kyle (1985) and Glosten and Milgrom (1985) predicted that different information among market participants would increase the risk of adverse selection by fund providers. Accordingly, fund providers demand higher compensation and widen the spread between the bid price and the asking price, which will reduce 
liquidity and increase the cost of capital. As a result, the determinants and consequences of earnings quality become an interest for investors, managers, regulators, and standard setters.

Campbell et al. (2001) found that poor earnings quality related to company volatility. Increasing numbers of new companies and much less profitable in initial public offerings affect the quality of earnings of the company, as well as improve the usefulness of information for sophisticated investors that would further worsen the information asymmetry. Also, there is a theoretical debate about whether earnings quality affects the cost of equity. Francis et al. $(2005 ; 315)$ tested whether the accruals quality is a determinant of the cost of equity. This study found that earnings quality affected the cost of equity economically and statistically significant. Francis et al. (2005) made a conclusion based on the assumption that the information risk was a risk factor that was reflected in the price.

Core et al. (2008) found that time-series regression of companies' stock return that was the object of Francis et al. (2005) research did not examine whether accrual quality was a risk factor that is reflected in the price. Whether information risk can be diversified or not is still questionable in the literature. This study is expected to contribute to the debate by testing whether information asymmetry mediates the relationship between poor earnings quality relationships and a high cost of equity.

\section{Literature Review and Hypothesis Development}

\subsection{Earnings Quality}

Earnings quality related to the ability of a company's reported earnings to estimate the company's actual earnings in the future. Schipper and Vincent (2003) suggested three criteria of earnings quality: persistence, ability to predict, and relatively low variability.

According to another opinion, Dechow et al. (2010) stated that earnings quality was high if they met the following characteristics: 1) reflected accurately the company's operational performance, 2) provided a good indicator of the performance of the company in the future, and 3) served as a measure to assess the company. Dechow et 
al. (2010) also stated that good earnings quality was able to represent the process of the company's reported earnings and useful for decision-making for its users.

Earnings information must have integrity; the earnings numbers are not generated from business management to manipulate earnings to increase a company's reported earnings. Earnings information must also be reliable; profit can provide a good indicator of the company's performance.

\subsection{Information Asymmetry}

Information asymmetry occurs when one of the parties (traders) have superior information than the other parties that enable them to take advantage and leaving others with the loss. In such a situation, private information was only received by informed traders (Hartono, 2013).

The perspective of information asymmetry implies that managers strive to maximize the value of the company in self-interested ways (i.e., opportunistic). Quality of accounting information is useful in reducing information asymmetry. When information asymmetry occurs, the disclosure of decisions made by managers can influence stock prices because of the gap between informed investors and less informed investors will create a cost of transactions and reduce the expected liquidity in the market (Komalasari, 2000).

\subsection{Cost of Equity}

The cost of equity is the rate of return expected by equity investors is a premium for equity risk in investment. It is the rate of return demanded by investors on an equity investment in a company.

One of the simplest and the most widely used models to estimate the cost of capital is by using the Capital Asset Pricing Model (CAPM). CAPM model is an essential part of the financial sector that is used to predict the relationship between the expected return (historical data) and the risk of an asset. CAPM that developed by Sharpe (1964) and Lintner (1965) is one of many tools in finance that can be used to estimate the cost of 
equity, in which case the expected rate of return is a function consisting of the risk-free rate and the market-specific risk premium (Bodie et al., 2009: 280).

\subsection{Prior Research and Hypothesis Development}

\subsubsection{Earnings Quality and Information Asymmetry}

There are several models of research on how earnings information can affect information asymmetry, of which Verrechia (1982) concluded that an increase of public information lowers the cost of the search for private information. Increased public information also reduced the incentive for investors who do not obtain private information and reduced speculative behavior among investors (Callahan, 1997: 51).

Diamond (1985) and Diamond and Verrechia (1991) showed that high-quality financial reporting could reduce the level of information asymmetry among traders and reduced the cost of equity. Battacharya et al. (2011) reported that poor earnings quality significantly affects high information asymmetry. Prior studies suggested that when public companies announced earnings with poor quality, they tend to have higher information asymmetry. Accordingly, this study hypothesizes:

H1: A company with poor earnings quality will have higher information asymmetry.

\subsubsection{Information Asymmetry and Cost of Equity}

Securities and Exchange Commission (SEC) (2000) revealed that selective disclosure leads to adverse selection behavior (information asymmetry), which would trigger demand premium by investors for higher risk assets, therefore increasing the company's higher cost of equity. The differences in information distribution among market participants lead to a difference in expectations of trading security. Specifically, Easley and O'Hara (2004) analyzed the differences between public information and private information. They argued that less informed traders recognized themselves as less advantaged in terms of acquisition of information, and just kept fewer assets as a consequence. It would cause the securities to become illiquid with a high degree of private information (information asymmetry) (Lambert et al., 2011). 
The empirical model initiated by Callahan et al. (1997) showed the relationship between accounting information and the bid-ask spread. Research by Callahan et al. (1997) was based on the premise that there were parties with more information about the real value of the company compared to others, which then lead to the bid-ask spread.

Theoretically, Amihud and Mendelson (1996) stated that securities with a wide range of bid-ask spread tend to have a higher cost of equity so that investors demanded higher returns as compensation for the additional cost of a transaction.

H2: A company with higher information asymmetry will have a higher cost of equity.

\subsubsection{Earnings Quality, Information Asymmetry, and Cost of Equity}

Poshakwale and Courtis (2005) stated the more disclosures, the lower uncertainty of investors, at the condition of ceteris paribus, especially if the disclosure contained accounting information. At the lower uncertainty, investors will be more willing to accept a lower dividend payment. The low dividend payout will reduce the cost of equity because of low expected risk by investors. It lowers the interest cost of investment activities, thus increasing the chances of the company to get higher profitability project, investors will be expected to react positively to the payment of dividends in the future. The low risk expected by investors means low cost of equity for the company. Based on that, the model of the association between earnings quality and cost of equity through information asymmetry as follows:

Gambar 1.

Research Design

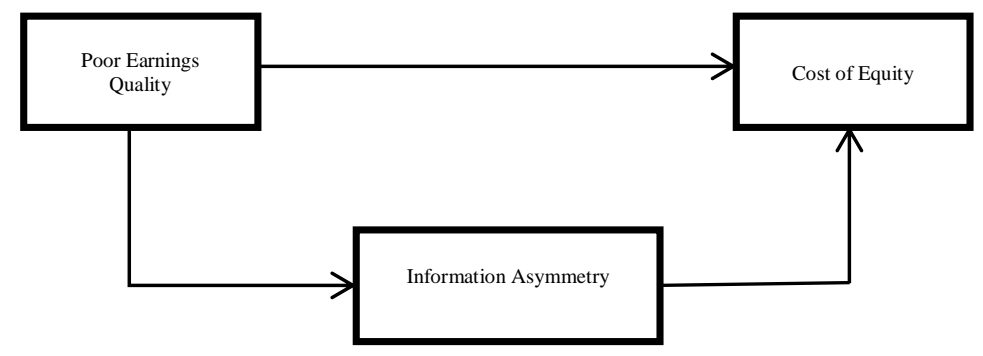


Based on the explanation above, we propose the following hypothesis:

H3: The negative association between earnings quality and cost of equity in a company is mediated through its information asymmetry

\section{Research Design}

\subsection{Data and Sample}

This study uses companies in the manufacturing industries listed on the Indonesia Stock Exchange from 2007 to 2011. This study period is based on the consideration that starting in 2012, the reporting standards in Indonesia are fully convergent with IFRS. We select companies in the manufacturing industry because it dominates the number of listed companies, compare to other industry (142 out of 459, fact book 2013) with more diverse industry characteristics.

\subsection{Measurement}

\subsubsection{Independent Variable: Earnings Quality (X)}

This study uses the absolute discretionary accruals (|DA|), modified Jones model (1991) to measure earnings quality. Higher discretionary accruals represent lower earnings quality. Here are the steps to determine the $|\mathrm{DA}|$ :

1. Regress companies in the manufacturing industry using the modified Jones model to obtain the value of $\alpha, \beta \_1$, dan $\beta_{-} 2$.

$$
\frac{\text { TACC }_{i . t}}{\text { Asset }_{i . t-1}}=\alpha+\beta_{1} \frac{\Delta R E V_{i . t}}{\text { Asset }_{i . t-1}}+\beta_{2} \frac{P P E_{i . t}}{\text { Asset }_{i . t-1}}+\varepsilon_{i . t}
$$

Where:

$$
\begin{array}{ll}
\operatorname{TACC}_{i . t}= & \text { total current accruals (net income }- \text { cash flow from the operation) in year } \mathrm{t} \text { for } \\
& \text { firm } \mathrm{i} \\
\text { Asset }_{i . t-1}= & \text { total asset in year } \mathrm{t} \text { for firm } \mathrm{i} \\
\Delta R E V_{i . t}= & \text { change in revenue at the period } \mathrm{t} \text { and } \mathrm{t}-1 \\
C F O_{i . t} & =\text { cash flow from operation } \\
P P E_{i . t} & =\text { Gross value of Plant, Property, and Equipment at the period } \mathrm{t} \text { for firm } \mathrm{i}
\end{array}
$$




$$
\begin{array}{ll}
\Delta C A_{i t} & =\text { change in a current asset at the period } \mathrm{t}-1 \text { and } \mathrm{t} 1 \\
\boldsymbol{\varepsilon}_{i . t} & =\text { error term in year } \mathrm{t} \text { for firm } \mathrm{i}
\end{array}
$$

2. Calculating the value of non-discretionary accrual by using the following formula:

$$
N D A_{J . t}=\hat{\alpha} \frac{1}{\text { Asset }_{i . t-1}}+\hat{\beta}_{1} \frac{\Delta R E V_{i . t}}{\text { Asset }_{i . t-1}}+\hat{\beta}_{2} \frac{P P E_{i . t}}{\text { Asset }_{i . t-1}}
$$

3. Determine the value of discretionary accruals by using the following formula:

$$
D A_{J . t}=\frac{T_{A C C} i . t}{\text { Asset }_{i . t-1}}-N D A_{J . t}
$$

\subsubsection{Dependent Variable: Information Asymmetry $(M)$}

Information asymmetry is measured using the bid-ask spread. It operated as follows:

$$
\text { SPREADit }=\frac{\left(a s k_{i t}-b i d_{i t}\right)}{\left(a s k_{i t}+b i d_{i t}\right) / 2}
$$

Spread is a proxy of information asymmetry, askit is the sales offer price of shares, and bidit is a firm purchase price of firm $i$ at the period t. Information asymmetry obtained from market data at the date of a financial statement published until the 5th day $(\mathrm{H} 0-\mathrm{H}+5)$.

\subsubsection{Dependent Variable: Cost of Equity $(Y)$}

According to the CAPM method (Sharpe, 1964, cited in Hartono, 2013: 529), the calculation of the cost of equity is written in the following formula:

$$
E\left(R_{i}\right)=R_{B R}+\beta_{I}\left(E\left(R_{m)}-R_{B R}\right)\right.
$$

Where:

$$
\begin{array}{cl}
E\left(R_{i}\right) & =\text { expected return } \\
R_{B R} & =\text { risk-free rate } \\
\beta & =\text { systematic risk } \\
R_{m} & =\text { market return }
\end{array}
$$




\subsection{Diagnostic Tests}

Before the hypotheses testing, the data need to be examined for any deviations from normality and BLUE assumptions, including a multicollinearity test by observing the value of variance inflating factor (VIF), autocorrelation test with Durbin Watson (DW) statistical testing, and heteroscedasticity test with Glejser test.

\subsection{Mediation Tests}

Mediation test consists of two alternatives, the first is a causal step initiated by Baron and Kenny (1986), and the second alternative is initiated by Rucker et al. (2011).

\subsubsection{First Alternative}

According to Baron and Kenny (1986: 1177) there are three stages to test the mediating effect, known as causal steps, they are:

1. In the first step, examine the effect of the independent variable $(\mathrm{X})$ to the mediating variable $(\mathrm{M})$, and significant at $\mathrm{P}<0.05$.

$\operatorname{SPREAD}_{i, t}=\alpha_{1}+\beta_{1} D A_{i, t-1}+\beta_{2} \operatorname{SIZE}_{i, t}+\beta_{3} Y E A R+\mathrm{e}_{t}$

Where:

SPREAD $_{i, t} \quad=$ information asymmetry in year $\mathrm{t}$ of firm $\mathrm{i}$

$D A_{i, t-1}=$ discretionary accruals in year $\mathrm{t}$ for firm $\mathrm{i}$

$S I Z E_{i, t} \quad=$ company size; market capitalization

YEAR = dummy variable, when financial statement published

2. The second step, examine the effect of mediating variable $(\mathrm{M})$ to the dependent variable $(\mathrm{Y})$, and significant at $\mathrm{P}<0.05$.

$\mathrm{CoE}_{i, t}=\alpha_{2}+\beta_{4} S P R E A D_{i, t-1}+\beta_{5} S I Z E_{i, t}+\beta_{6} Y E A R+\mathrm{e}_{t}$

3. The third step, examine the effect of the independent variable, mediating variable (M), and dependent variable (Y) simultaneously.

$$
\mathrm{CoE}_{i, t}=\alpha_{3}+\beta_{7} D A_{i, t-1}+\beta_{8} S P R E A D_{i, t}+\beta_{9} S I Z E_{i, t}+\beta_{10} Y E A R+\mathrm{e}_{t}
$$

The three equations above examine the relationship between variables in the model of mediation, and the effect of mediation occurs when (1) a significant influence on the 
independent variables to mediators in the 6th equation, (2) significant influence of mediating variables on the dependent variable in the 7th equation, (3) significant influence of variables independent of the dependent variable in the 8th equation, and (4) direct influence of independent variables on the dependent variable is reduced in the presence of mediators (Baron and Kenny, 1986; 1177). The significance test of mediation models uses the Sobel (1982) model.

\subsubsection{Second Alternative}

Preacher and Hayes (2004) stated that the critical component of the analytical procedure of mediation test is the significance of indirect effect $(a \times b)$. Although the analytical procedures recommended by Baron and Kenny (1986) are more commonly used, the method is intended only for the data with a large sample size (Preacher and Hayes, 2008).

Baron and Kenny (1986) stated that the Sobel test could be used as a significant test for the indirect effect of the mediation model. Sobel test required normal distribution data. However, it is challenging to meet this assumption. Preacher and Hayes (2008) recommend the use of bootstrapping, non-parametric statistical tests with resampling procedure, which is used for testing mediation and do not require normal distribution data. Bootstrapping is recommended to test mediation as compared with the Sobel test (Preacher and Hayes, 2008). This is to avoid a Type I error when a normal distribution cannot be met.

\section{Results and Discussion}

The sample in this study is selected using purposive sampling according to the criteria. This study uses 381 manufacturing companies from 2007 to 2011.

\subsection{Descriptive Statistics}

Table 2 (see appendix) shows the descriptive statistics of variables, discretionary accruals (DA), market capitalization or SIZE, and CAPM during the observation year, from 2007 to 2011, and SPREAD in 2008 to 2012, the year in which the financial 
statements released. Jembo Cable Company Tbk (JECC) in 2010 shows that the minimum value of $|\mathrm{DA}|$ is 0.000 , while the maximum value of 0.4658 is shown by PT Asia Pacific Fibers Tbk (POLY) in the same year. The average |DA | of 0.0809 and the standard deviation of 0.0800 is relatively more substantial than the average value, and standard deviation of ABSDA or absolute discretionary accruals reported on Fatmawati and Sabeni (2013)'s study (i.e., 0.0217 and 0.0550) in 2011. The high value of $\mid$ DA | denotes the magnitude of the company's discretionary accrual, which indicates lower earnings quality.

The lowest SPREAD of 0.0018 is shown by the share transactions of PT Gudang Garam Tbk (GGRM) in 2010, and the highest SPREAD of 0.5341 is indicated by the stock transaction Kedaung Indah Can. Tbk (KICI) in 2007. The average SPREAD of 0.0497 and the standard deviation of 0.1138 are relatively lower than those of 0.39249 and 0.18754 reported in the study of Ningrum (2010). A higher SPREAD value indicates high information asymmetry. Thus, companies in this study show relatively lower information asymmetry compared to information asymmetry reported by Ningrum (2010).

The smallest SIZE of the company's market capitalization of Rp4,62 billion is indicated by Siwani Makmur PT TBK (SIMA) in 2008, and the most significant companies size of 173,273 billion is shown by PT Hanjaya Mandala Sampoerna Tbk (HMSP) in 2011. PT Kertas Basuki Rachmat Indonesia Tbk shows the minimum value of CAPM (-1.0744). (KBRI) in 2009, and the maximum value (2.2426) is shown by PT Lotte Chemical Titan Tbk. (FPNI) in 2009. The average CAPM (0.6833) and the standard deviation (0.4665) are relatively higher than the CAPM value reported in the study Susanto and Siregar (2012), with a study period in 2009 (0.1354 and 0.0444).

\subsection{Diagnostic Test}

As shown in Table 3, Model 1 is normally distributed; however, Model 2 is not distributed normally. Tolerance values in table 4 show less than 0,1 , and VIF values show greater than 10 . Therefore, there is no serious threat of multicollinearity between 
the independent variable in the model. The statistical test shows Durbin-Watson (DW) value (1.946) in between $\mathrm{dU}$ and 4-DU $(1.679<\mathrm{DW}<2.321)$, we may conclude that there is no autocorrelation. Glejser test shows a significant result so that there is multicollinearity in this model.

Overall, the diagnostic tests show that these research models meet the assumption of multicollinearity and autocorrelation, but do not meet the assumptions of normality and heteroscedasticity. Following Rucker et al. (2011), this study uses the second alternative to test mediation, as the first alternative requires normal data distribution.

\subsection{Multivariate Tests}

Bootstrapping is used to test the hypothesis following Hayes (2014). Bootstrapping is a method to estimate standard error and interval for coefficient correlation or regression, which cannot meet classic assumptions (Widiarso, 2012).

\subsubsection{Earnings Quality and Information Asymmetry}

Hypothesis 1 tests whether poor earnings quality, which is measured by absolute discretionary accruals, affects high information asymmetry (SPREAD), with company size (SIZE) and year (D2007, D2008, D2009, and D2010) as the covariate variables. The result is reported in Table 7 (see appendix).

The value of $\mathrm{R}^{2}$ in Table 7 (see appendix) is 0.3267 . It means that the independent variable explains $32.67 \%$ of the variation of the independent variable. The remaining $67.33 \%$ is explained by other factors. The coefficient of $|\mathrm{DA}|$ is $0.0058(p<0.05)$. It indicates a positive association between discretionary accruals and information asymmetry, suggesting that firms with higher earnings quality tend to have lower information asymmetry. This supports hypothesis 1 . The coefficient of SIZE is -0.0135 $(p<0.001)$. Thus larger companies tend to have lower information asymmetry. The dummy years' coefficients are all significant, i.e. $0.0466(p<0.01), 0.0182(p<0.05)$, $0.0091(p<0.01)$, and $0.0111(p<0.01)$ for 2007, 2008, 2009, and 2010, respectively. 


\subsubsection{Information Asymmetry and Cost of Equity}

Hypothesis 2 tests whether asymmetry information (SPREAD) affects the cost of equity (CAPM), with company size (SIZE) and year (D2007, D2008, D2009, and D2010) as the covariate variables. The result is presented in Table 8 (see appendix). The value of $\mathrm{R}^{2}$ in Table 8 (see appendix) is 0.3267 . It means that the independent variable explains $32.67 \%$ of the variation of the independent variable. The remaining $67.33 \%$ is explained by other factors.

The coefficient of $|\mathrm{DA}|$ are $-0.0153(p=-0.4068)$. Thus $|\mathrm{DA}|$ does not have a significant effect on the cost of equity. Accordingly, hypothesis 2 is not supported. SPREAD shows the coefficient of $-1.3122(p<0.01)$, showing that information asymmetry has a significant and positive association with the cost of equity. The finding does not support hypothesis 2 , which predicts that higher information asymmetry is associated with a higher cost of equity.

\subsubsection{Earnings Quality, Information Asymmetry, and Cost of Equity}

Table 9 (see appendix) shows the test result of the mediation test using bootstrapping. The value of $\mathrm{R}^{2}$ in this model is 0.0715 . It means that the independent variable explains $7.15 \%$ of the variation of the dependent variable. The remaining $92.85 \%$ is explained by other factors.

The coefficient value of path a, which tests the association between earnings quality and information asymmetry, is $0.0058(p<0.05)$. This shows that earnings quality significantly affects information asymmetry. A higher $|\mathrm{DA}|$ represents a lower quality of earnings. The coefficient value of path $b$, the association between information asymmetry and cost of equity, is $-1.3122(p<0.05)$. This indicates that information asymmetry significantly affects the cost of equity. The negative coefficient value shows the negative association between information asymmetry and the cost of equity.

The coefficient value of path $a$ and $b$ (indirect effect) is -0.0076 but not significant. Therefore hypothesis 3 is not supported. The mediating effect of information asymmetry on the association between poor earnings quality and the cost of equity is 
not supported in this research. This is not in line with the results of the study by Bhattacharya et al. (2012), which states that poor earnings quality affects the cost of equity through information asymmetry.

\section{Conclusion, Implication, and Limitation}

\subsection{Conclusion}

This research examines the effect of earnings quality on the cost of equity and whether information asymmetry affects the relationship as a mediator. We find that poor earnings quality (i.e., discretionary accruals) positively affects information asymmetry. This finding suggests that when earnings quality is poor, the information asymmetry will increase.

Further, this study finds a negative association between information asymmetry and cost of equity; thus, higher information asymmetry is associated with a lower cost of equity. This finding is not in line with the proposed hypothesis 2 , which predicts that a higher the information asymmetry will result in a higher cost of equity. Lastly, we find that poor earnings quality negatively affects the cost of equity through information asymmetry, suggesting that poor earnings quality will lower the costs of equity with the presence of information asymmetry. This is not in line with the proposed hypothesis 3 , which predicts that information asymmetry mediates the association between poor earnings quality and high cost of equity.

\subsection{Limitation}

The results show a negative correlation between poor earnings quality with the cost of equity and also a negative correlation between information asymmetry with the cost of equity; thereby, hypotheses 2 and 3 are not supported. The use of CAPM as the proxy for the cost of equity is an alternative explanation over the result. Diegnau and Masten (2014), and Fama and French (2004) stated that the use of the CAPM as proxy for cost of equity was less precise because CAPM only took market risk into account and not included other factors such as the size of the company (size) and the company's value (value) (three-factor model). Also, the cost of equity should also include the analysis of 
the value line, dividend forecast, and dividend growth rate, such as initiated by Brav et al. (2005).

\subsection{Recommendation}

Based on the results and limitations of this study, we suggest future studies to use another proxy to determine the cost of equity, for example, the three-factor models, as suggested by Diegnau and Masten (2014), and Fama and French (2004). Further, future studies should also add other variables that can affect the cost of equity, such as the probability of informed trading (PIN), adverse selection as a component of information asymmetry, and corporate disclosure policies.

\section{Reference}

ADBI. 2014. ASEAN 2030, Toward a Borderless Economic Community. Retrieved from http://www.adbi.org/files/2014.07.18.book.asean.2030.borderless.economic.communit y.pdf on 29 November 2014.

Amihud, Yakov dan Mendelson, Haim. 1989. The Journal of Finance. Vol. XLIV. No 2. 479 486.

Bhattacharya, Nilabhra., Desai, Hemang, and Venkarataman, Kumar. 2011. Does Earnings Quality Affect Information Asymmetry? Evidence from Trading Cost.

Bhattacharya, Nilabhra., E, Frank., Olsson, Per M., Schipper, Katherin. (2012) "Direct and Mediated Associations Among Earning Quality, Information Asymmetry, and the Cost of Equity." Vol. 87, No 2. 2012. 449-482

Barnes, M. L., and Lopez, J. A. 2006. Alternative measures of the Federal Reserve Banks' cost of equity capital. Journal of Banking and Finance. No 30. 1687-711.

Baron, R. M., and Kenny, D. A. 1986. The Moderator-Mediator Variable Distinction in Social Psychology Research: Conceptual, Strategic, and Statistical Considerations. Journal of Personality and Social Psychology. No. 6. 1173-1182.

Bodie, Z., Kane, A., and Marcus, A. J. 2009. Investments. New York: McGraw Hill International Edition.

Brigham, E. F., and Houston, J. F. 2007. Essential of Financial Management. Singapore: Cengage Learning Asia Pe Ltd. 
Campbell, J. Y., Lettau, M., Malkiel, B. G., and Xu, Y. 2001. Have Individual Stocks become More Volatile? Ab Empirical Exploration of Idiosyncratic Risk.

Copeland, T., and D. Galai. 1983. Information Effects on Bid-Ask Spread, Journal of Finance 38, December, Hal. 1457 - 1469.

Callahan, C. M., Lee, C. M. C., and Yohn, Teri L. 1997. Accounting Information and Bid-Ask Spread. Accounting Horizons. Vol. 11 No. 4. 50-60.

Core, J., Guay, W., and Ferdi, R. 2008. Is Accruals Quality a Priced Risk Factor. Journal of Accounting and Economics. No. 46. 2-22.

Dechow. P. M., and Schrand, C. M. 2004. Earnings Quality. Research Foundation of CFA Institute. The United States of America.

Dechow. P. M., Ge, Weili, and Schrand, Catherine M. 2010. Understanding Earnings Quality: A Review of The Proxies, Their Determinants, and Their Consequences.

Diagnau, P., and Masten, L. B. 2014. The Cost of Equity and the Fama-French Three-Factor Model. A Professional Development Journal for Consulting Disciplines.

Diamond, D. 1985. Optimal Releases Information by Firms. Journal of Finance 40(4): 10711094.

Diamond, D., and Verrechia, Robert E. 1991. Disclosure, Liquidity, and the Cost of Capital. The Journal of Finance. Vol XLVI, No. 4. 1325-1359.

Easley, D., and O'Hara. 2004. Information and the Cost of Capital. Journal of Finance59. 155383

Fama, E. F., French, K. R. 2004. The Capital Asset Pricing Model: Theory and Evidence. Journal of Economic Perspectives. Vol 3. Summer 2004. 25-46.

Fatmawati, D. dan Sabeni, A. 2013. Pengaruh Diversifikasi Geografis, Diversifikasi Industri, Konsentrasi Kepemilikan Perusahaan, dan Masa Perikatan Audit terhadap Manajemen Laba. Dipenonegoro Journal of Accounting. Vol. 2 No. 2. 2337-3806

Francis, J., LaFond, R., Schipper, K. 2005. The Market Pricing of Accruals Quality. Journal of Accounting and Economics. No. 39. 295-327.

Glosten, L. R., and Harris, Lawrence E. 1988. Estimating The Components of the Bid/Ask Spread. Journal of Financial Economics 21. 123-142.

Glosten, L. R., and Milgrom. 1985. Bid, Ask, and Transaction prices in specialist market with heterogeneously informed traders. Journal of Financial Economics: Hal 71-100.

Hayes, A. F. 2013. Introduction to Mediation, Moderation, and Conditional Process Analysis. A Regression-Based Approach. The Guilford Press. New York. 
2014. The PROCESS macro for SPSS and SAS. Retrieved from http://www.processmacro.org/download.html. on 02 April 2015.

Hartono, J. 2013. Teori Portofolio dan Analisis Investasi. BPFE. Yogyakarta.

Komalasari, P. T., \& Baridwan, Zaki. 2001. Asimetri Informasi dan Cost of Capital. Jurnal Riset Akuntansi Indonesia, Vol.4, No. 1, 64-81.

Kyle, A. S. 1985. Continuous auction and insider trading. Econometrica 53. 1315-1335

Lambert, R. A., Leuz, Christian., Verrecchia, Robert E. 2012. Information Asymmetry, Information Precision, and the Cost of Capital. Review of Finance. 16 (1): 1-29.

Ningrum, D. W. 2010. Analisis Pengaruh Spread, Kepemilikan Manajerial, Rasio Pasar, Rasio Aliran Kas, dan Rasio Leverage terhadap Kebijakan Dividen. Tesis. Magister Ekonomi Pembangunan.

Poshakwale, Sunil, and John K. Courtis. 2005. Disclosure Level and Cost of Equity Capital: Evidence from the Banking Industry. Managerial and Decision Economics: Wiley InterScience.

Preacher, K. J., and Hayes, A. F. 2008. Asymptotic and Resampling Strategies for Assessing and Comparing Indirect Effects in multiple mediator models. Behavior Research Methods. 40 (3). 879-891.

PWC. 2011. Point of View: Reducing Complexity. Retrieved from http://www.pwc.com/us/en/point-of-view/reducing-complexity.jhtml on 20 November 2014.

Rucker, D. D., Preacher, K. J., Tormala, Z. L., and Petty, R. E. 2011. Mediation Analysis in Social Psychology: Current Practices and New Recommendations. Social and Personality Psychology Compass 5/6. 359-371.

Schipper, Katherine, and Vincent, Linda. 2003. Earnings Quality. Accounting Horizons. 97-110.

SEC. 2000. Final Rule: Selective Disclosure and Insider Trading. The US. Retrieved from http://www.sec.gov/rules/final/33-7881.htm on November 2014

Sharpe, W. 1964. Capital Asset Prices: A Theory of Market Equilibrium under Conditions of Risk. Journal of Finance. 425-442

Shrout, P. E., and Bolger, N. 2002. Mediation in Experimental and Nonexperimental Studies: New Procedures and Recommendations. Psychological Methods. 7(4). 422-445.

Sobel, M. E. 1982. Asymptotic Confidence Intervals for Indirect Effects in Structural Equation Models. Sociological Method. 290-312 
Susanto, S. dan Siregar, S. V. 2012. Corporate Governance, Kualitas Laba, dan Biaya Ekuitas: Studi Empiris Perusahaan Manufaktur yang Terdaftar di Bursa Efek Indonesia Tahun 2009. Skripsi. Fakultas Ekonomi . Akuntansi. Universitas Indonesia.

\section{APPENDIX}

Table 1

Investment Development

\begin{tabular}{|c|c|c|c|r|}
\hline Year & $\begin{array}{c}\text { Number of } \\
\text { Companies }\end{array}$ & $\begin{array}{c}\text { Transaction Volume } \\
\text { (Milion Shares) }\end{array}$ & $\begin{array}{c}\text { Transaction } \\
\text { Frequency }\end{array}$ & $\begin{array}{c}\text { Stock } \\
\text { Issuance }\end{array}$ \\
\hline 2004 & 331 & 411.768 & 3.724 & 2.141 \\
\hline 2005 & 336 & 401.868 & 4.012 & 3.545 \\
\hline 2006 & 344 & 436.936 & 4.811 & 3.005 \\
\hline 2007 & 383 & 1.039 .542 & 11.861 & 16.868 \\
\hline 2008 & 396 & 787.846 & 13.417 & 24.388 \\
\hline 2009 & 398 & 1.467 .659 & 20.977 & 3.854 \\
\hline 2010 & 420 & 1.330 .865 & 25.919 & 29.678 \\
\hline 2011 & 440 & 1.203 .550 & 28.023 & 19.593 \\
\hline 2012 & 462 & 1.053 .762 & 29.941 & 10.234 \\
\hline 2013 & 483 & 1.342 .657 & 37.499 & 16.747 \\
\hline
\end{tabular}

Source: IDX Fact Book 2004 - 2013

Tabel 2

Variable Statistics Descriptive

\begin{tabular}{|c|c|c|c|c|c|}
\hline & $\mathrm{N}$ & Min & Max & Mean & Std. Deviation \\
\hline$|\mathrm{DA}|$ & 381 & 0,0000 & 0,4658 & 0,0809 & 0,0800 \\
\hline SPREAD & 381 & 0,0018 & 0,5342 & 0,0497 & 0,0748 \\
\hline SIZE & 381 & 4.625 .000 & 173.272 .990 .800 & 5.851 .125 .960 & 18.294 .848 .943 \\
\hline CAPM & 381 & $-1,0744$ & 2,2426 & 0,6833 & 0,4666 \\
\hline
\end{tabular}

$|\mathrm{DA}|=$ absolut discretionary accrual, SPREAD=information asymmetry, SIZE=market capitalization (thousand rupiah, CAPM=cost of equity. 
Tabel 3

Diagnostic Test

Normality Test

\begin{tabular}{|c|c|c|c|c|c|}
\hline \multicolumn{2}{|c|}{ Model Hipotesis 1} & $\begin{array}{c}\text { Unstandardized } \\
\text { Residual }\end{array}$ & \multicolumn{2}{|c|}{ Model Hipotesis 2 dan 3} & $\begin{array}{c}\text { Unstandardized } \\
\text { Residual }\end{array}$ \\
\hline \multicolumn{2}{|l|}{$\mathrm{N}$} & 381 & $\mathrm{~N}$ & & 381 \\
\hline Normal & Mean & 0 & Normal & Mean & 0 \\
\hline Parameters ${ }^{\mathrm{a}, \mathrm{b}}$ & $\begin{array}{l}\text { Std. } \\
\text { Deviation }\end{array}$ & 0.06670843 & Parameters ${ }^{\mathrm{a}, \mathrm{b}}$ & $\begin{array}{l}\text { Std. } \\
\text { Deviation }\end{array}$ & 0.44096 \\
\hline \multirow{3}{*}{$\begin{array}{l}\text { Most Extreme } \\
\text { Differences }\end{array}$} & Absolute & 0.194 & Most & Absolute & 0.026 \\
\hline & Positive & 0.194 & Extreme & Positive & 0.026 \\
\hline & Negative & -0.122 & Differences & Negative & -0.02 \\
\hline \multicolumn{2}{|c|}{ Kolmogorov-Smirnov Z } & 3.795 & \multicolumn{2}{|c|}{ Kolmogorov-Smirnov Z } & 0.516 \\
\hline \multicolumn{2}{|c|}{ Asymp. Sig. (2-tailed) } & $\mathbf{0}$ & \multicolumn{2}{|c|}{ Asymp. Sig. (2-tailed) } & 0.953 \\
\hline
\end{tabular}

Table 4

Multicollinearity Test

\begin{tabular}{|ll|r|r|}
\hline \multirow{2}{*}{ Model } & \multicolumn{2}{|c|}{$\begin{array}{c}\text { Collinearity } \\
\text { Statistics }\end{array}$} \\
\cline { 3 - 4 } & & Tolerance & \multicolumn{1}{c|}{ VIF } \\
\hline 1 & (Constant) & & \\
& |DA| & 0.978 & $\mathbf{1 . 0 2 2}$ \\
& SPREAD & 0.796 & $\mathbf{1 . 2 5 7}$ \\
SIZE & 0.838 & $\mathbf{1 . 1 9 4}$ \\
D2007 & 0.652 & $\mathbf{1 . 5 3 3}$ \\
D2008 & 0.717 & $\mathbf{1 . 3 9 4}$ \\
D2009 & 0.644 & $\mathbf{1 . 5 5 2}$ \\
D2010 & 0.669 & $\mathbf{1 . 4 9 4}$ \\
\hline
\end{tabular}

Table 5

Autocorrelation Test

\begin{tabular}{|c|c|c|c|c|c|c|c|}
\hline \multirow[b]{2}{*}{$\mathrm{R}$} & \multirow[b]{2}{*}{$\begin{array}{c}\mathrm{R} \\
\text { Square }\end{array}$} & \multicolumn{5}{|c|}{ Change Statistics } & \multirow[b]{2}{*}{$\begin{array}{l}\text { Durbin- } \\
\text { Watson }\end{array}$} \\
\hline & & $\begin{array}{c}\mathrm{R} \\
\text { Square } \\
\text { Change }\end{array}$ & $\begin{array}{c}\mathrm{F} \\
\text { Change }\end{array}$ & df1 & df2 & $\begin{array}{l}\text { Sig. F } \\
\text { Change }\end{array}$ & \\
\hline $.327^{\mathrm{a}}$ & 0,107 & 0,107 & 6.366 & 7 & 373 & 0 & 1.946 \\
\hline
\end{tabular}

a. Predictors: (Constant), SPREAD, D2009, |DA|, D2008, D2010,

SIZE, D2007

b. Dependent Variable: CAPM 
Tabel 6

Heteroscedasticity Test

\begin{tabular}{|c|c|c|c|c|c|c|}
\hline & \multicolumn{2}{|c|}{$\begin{array}{l}\text { Unstandardized } \\
\text { Coefficients }\end{array}$} & \multirow{2}{*}{$\begin{array}{c}\text { Standardized } \\
\text { Coefficients } \\
\text { Beta } \\
\end{array}$} & \multirow[b]{2}{*}{$\mathrm{t}$} & \multirow[b]{2}{*}{ p-value } \\
\hline & & B & $\begin{array}{l}\text { Std. } \\
\text { Error }\end{array}$ & & & \\
\hline & (Constant) & .162 & .165 & & .983 & .326 \\
\hline & $|\mathrm{DA}|$ & .003 & .011 & .012 & .240 & .810 \\
\hline & SIZE & .008 & .008 & .057 & 1.026 & .306 \\
\hline & D2007 & -.005 & .045 & -.008 & -.120 & .905 \\
\hline & D2008 & .016 & .048 & .021 & .345 & .731 \\
\hline & D2009 & .041 & .040 & .065 & 1.022 & .307 \\
\hline & D2010 & -.014 & .042 & -.022 & -.346 & .730 \\
\hline & SPREAD & .523 & .208 & .144 & 2.519 & .012 \\
\hline
\end{tabular}

Tabel 7

Regression Result of Hypothesis 1

\begin{tabular}{|l|r|r|c|}
\hline Variable & Coefficient & $p$-value & $\begin{array}{c}\text { Expected } \\
\text { Direction }\end{array}$ \\
\hline Constanta & 0,3278 & 0,0000 & + \\
\hline$|\mathrm{DA}|$ & 0,0058 & 0,0106 & + \\
\hline SIZE & $-0,0135$ & 0,0000 & - \\
\hline D2007 & 0,0466 & 0,0000 & \\
\hline D2008 & 0,0182 & 0,0104 & \\
\hline D2009 & 0,0091 & 0,0081 & \\
\hline D2010 & 0,0111 & 0,0098 & \\
\hline Adj. $R^{2}$ & 0,3267 \\
\hline F-Stat. & $9,4644(p<0.001)$ \\
\hline
\end{tabular}

Table 8

Regression Result of Hypothesis 2

\begin{tabular}{|l|r|r|r|c|}
\hline Variabel & Coefficient & Coefficient & $p$-value & $\begin{array}{c}\text { Expected } \\
\text { Direction }\end{array}$ \\
\hline Konstanta & 0,2446 & 0,9189 & 0,3588 & + \\
\hline SPREAD & $-1,3122$ & 0,4511 & 0,0038 & - \\
\hline $\mid$ DA $\mid$ & $-0,0153$ & 0,0184 & 0,4068 & - \\
\hline SIZE & 0,023 & 0,0123 & 0,0611 & + \\
\hline D2007 & 0,1649 & 0,0681 & 0,0160 & \\
\hline D2008 & 0,0182 & 0,0756 & 0,4213 & \\
\hline D2009 & $-0,1224$ & 0,0702 & 0,0819 & \\
\hline D2010 & $-0,1032$ & 0,0634 & 0,1044 & \\
\hline Adj. $R^{2}$ & 0,3267 \\
\hline F-Stat. & $9,4644(p<0.001)$ \\
\hline
\end{tabular}


Tabel 9

Regression Result of Hypothesis 3

\begin{tabular}{|c|c|c|c|c|}
\hline Koefisien Regresi & Nilai & Prob & BootLLCI & BootULCI \\
\hline $\mathrm{a}$ & 0,0058 & 0,0106 & - & - \\
\hline $\mathrm{b}$ & $-1,3122$ & 0,0038 & - & - \\
\hline Indirect path & $-0,0076$ & - & $-0,2622$ & $-0,0174$ \\
\hline Adj. $\mathrm{R}^{2}$ & 0,3267 & \\
\hline F-Stat. & $9,4644(p<0.001)$ & \\
\hline
\end{tabular}


The Indonesian Journal of Accounting Research - Sept, Vol. 23, No.2, 2019

intentionally blank 